\title{
VIVE LA DIFFÉRENCE: DISAGGREGATION OF THE PRODUCTIVITY CONVERGENCE PROCESS *
}

\author{
S. N. BROADBERRY \\ University of Warwick
}

\section{RESUMEN}

Este trabajo examina el proceso de convergencia en perspectiva histórica a nivel desagregado. Tomando en consideración la producción, la renta y el gasto este trabajo muestra una gran diversidad geográfica y temporal. Cada país se especializó según su ventaja comparativa y la convergencia se produjo tanto a través de cambios en su estructura productiva, como a niveles microeconómicos. Asimismo, variaciones en la proporción de las facturas condujo a una mejor convergencia de la renta sin necesidad de una mayor aproximación de los precios de los factores. El trabajo demuestra también que persistieron importantes diferencias en las preferencias de los consumidores. Asi pués, el proceso de convergencia a nivel agregado no condujo necesariamente a la uniformidad de las economías. ¡Vive la differénce!

\section{ABSTRACT}

This paper examines the convergence process at a disaggregated level in a historical context. A three-way disaggregation of the national accounts by output, income and expenditure reveals a wealth of diversity, both over time and across

* This paper was originally prepared for the 1995 EHES Summer School, Groningen and has been aired subsequently at the ADIS conference, "Convergences-divergences en économie ouverte", Université de Paris Sud and the Economic History Seminar at Universidad Carlos III, Madrid. I thank participants for helpful comments and suggestions. Thanks also to the editor and anonymous referees of this journal for advice. Any remaining errors are my responsibility. 
countries, i.e. history and geography matter. Countries can specialise according to comparative advantage, and convergence at the aggregate level can occur through changes in structure as well as through convergence at the micro level. Similarly, changes in factor proportions may lead to convergence of aggregate incomes without requiring convergence of all factor prices at the micro level. Also, differences in preferences may persist, so that individual components of expenditure do not need to converge in line with aggregate expenditure. Convergence at the aggregate level, then, does not necessarily lead to uniformity. Vive la différence!

\section{INTRODUCTION}

Most of the work on the convergence of productivity and living standards among the advanced industrialised nations has been conducted at the aggregate level, using Maddison's (1982; 1991; 1995) well known national income data set (Baumol, 1986; Abramovitz, 1986; De Long, 1988; Feinstein, 1988). Here a breakdown of the aggregate picture is provided along three lines, using the traditional national accounting categories. The following questions are examined: 1) On the output side, has labour productivity converged by industry? Or have differences persisted at the level of individual industries despite convergence at the aggregate level? 2) On the income side, have real wages and other factor incomes converged? 3) On the expenditure side, have savings rates and the share of government in economic activity converged?

The disaggregated data reveal a wealth of diversity, even as convergence has occurred at the aggregate level. In short, convergence does not have to mean uniformity. Countries can specialise according to comparative advantage, and convergence at the aggregate level can occur through changes in structure as well as through convergence at the micro level. Similarly, changes in factor proportions may lead to convergence of aggregate incomes without requiring convergence of all factor prices at the micro level. Also, differences in preferences may persist, so that individual components of expenditure do not need to converge in line with aggregate expenditure.

\section{CONVERGENCE AND THE AGGREGATE DATA}

Data on national income and labour inputs for 16 advanced industrialised countries over the period since 1870 have been collected by Maddison 


\section{TABLE 1}

Comparative levels of aggregate labour productivity (US GDP per bour worked $=100$ )

\begin{tabular}{lccccccc}
\hline & 1870 & 1913 & 1929 & 1938 & 1950 & 1973 & 1992 \\
\hline Austria & 62 & 57 & 44 & 39 & 32 & 65 & 83 \\
Belgium & 94 & 70 & 64 & 61 & 48 & 70 & 98 \\
Denmark & 67 & 66 & 68 & 61 & 46 & 68 & 75 \\
Finland & 37 & 35 & 34 & 36 & 32 & 57 & 70 \\
France & 60 & 56 & 55 & 62 & 45 & 76 & 102 \\
Germany & 70 & 68 & 58 & 56 & 35 & 71 & 95 \\
Italy & 46 & 41 & 38 & 44 & 34 & 66 & 85 \\
Netherlands & 103 & 78 & 84 & 72 & 51 & 81 & 99 \\
Norway & 48 & 43 & 45 & 50 & 43 & 60 & 88 \\
Sweden & 54 & 50 & 44 & 49 & 56 & 77 & 79 \\
Switzerland & 77 & 63 & 72 & 68 & 69 & 78 & 87 \\
UK & 115 & 86 & 74 & 69 & 62 & 68 & 82 \\
Australia & 147 & 103 & 86 & 83 & 69 & 72 & 78 \\
Canada & 71 & 82 & 69 & 61 & 77 & 81 & 87 \\
USA & 100 & 100 & 100 & 100 & 100 & 100 & 100 \\
Japan & 20 & 20 & 24 & 25 & 16 & 48 & 69 \\
Average of 15 & 71 & 61 & 56 & 56 & 48 & 69 & 85 \\
CV & 0,44 & 0,34 & 0,31 & 0,27 & 0,34 & 0,13 & 0,12 \\
\hline
\end{tabular}

SOURCE: Maddison (1995), p. 47.

$(1964 ; 1982 ; 1991 ; 1995)$. The latest version of the basic data is set out in Table 1 , and is usually seen as consistent with the hypothesis that there has been unconditional convergence of labour productivity and living standards among the industrialised countries (Abramovitz, 1979; 1986; Baumol, 1986) ${ }^{~}$. However, it should be noted that Abramovitz $(1979 ; 1986)$ stressed the role of catch-up growth during the post-World War II period and was much more equivocal about earlier periods. The reasons for this caution are apparent in Table 1. The arithmetic average of GDP per hour worked in fifteen countries compared to the USA fell from 1870 to 1913 and continued to fall until 1950. Furthermore, the coefficient of variation (CV) fell only slightly between 1870 and 1913 and was just as high in 1950 as in 1913. Although there was a substantial fall in the CV between 1950 and 1973 , there was no further substantial fall after 1973. Given these fin-

1 We shall not concern ourselves in this paper with conditional convergence. See Broadberry (1996) for the distinction between conditional and unconditional convergence. 
dings, it is not surprising that Abramovitz chose to concentrate on the period 1950-73.

Furthermore, De Long (1988) has questioned the validity of a general inference of global convergence from an ex post sample of countries that are now rich and have developed successfully. Maddison's sample deliberately excludes nations that were relatively rich in 1870 but which have not developed successfully since and are now relatively poor. Hence convergence is all but guaranteed in Baumol's sample, but this tells us little about the forces making for convergence among the nations that in 1870 seemed likely to converge. If East Germany, Spain, Portugal, Ireland, Chile, Argentina and New Zealand, (all rich countries in 1870), are added to the Maddison sample and Japan (a poor country in 1870) excluded, we arrive at a sample of 22 «once-rich» nations, and convergence is much less clear.

Nevertheless, if we limit ourselves to the ex post sample of countries studied by Maddison, it seems clear that unconditional convergence has occurred over the long period since 1870 , although not as rapidly as might be thought from a consideration of the period 1950-73 alone. For the purposes of the rest of this paper, I shall accept the convergence hypothesis at the aggregate level and disaggregate by output, income and expenditure.

\section{DISAGGREGATION BY OUTPUT}

\subsection{Comparative Labour Productivity Levels in Manufacturing}

To the extent that convergence in levels of GDP per hour worked has occurred between the advanced industrial economies, it is usually attributed to technology transfer in manufacturing (Nelson and Wright, 1992; Gomulka, 1971; Cornwall, 1977). In this section we investigate this issue by examining directly data on labour productivity in manufacturing. I show that amongst the advanced industrial economies over the long run, levels and trends of productivity have often differed greatly between manufacturing and the whole economy. Except where otherwise stated, all future reference to the term labour productivity will refer to output per employee, since historical data on employment by sector are far more reliable than the equivalent hours data.

The data on comparative levels of labour productivity in manufacturing are presented in Table 2, drawing on the sample of countries in Broadberry $(1996 ; 1997 a)$. For a number of key countries the estimates are des- 


\section{TABLE 2}

Comparative levels of labour productivity in manufacturing (UK output per employee $=100$ )

\begin{tabular}{lrrrrrrr}
\hline & 1870 & 1913 & 1929 & 1938 & 1950 & 1973 & 1989 \\
\hline UK & 100 & 100 & 100 & 100 & 100 & 100 & 100 \\
USA & 204 & 213 & 250 & 192 & 263 & 215 & 177 \\
Canada & 88 & 153 & 170 & 145 & 151 & 153 & 123 \\
Australia & & 138 & 102 & 101 & 96 & 86 & 81 \\
Germany & 100 & 119 & 105 & 107 & 96 & 119 & 105 \\
Netherlands & & & 102 & 117 & 88 & 133 & 128 \\
Norway & & 90 & 109 & 95 & 103 & 104 & 85 \\
Sweden & & 102 & 94 & 100 & 118 & 128 & 121 \\
Denmark & & & 115 & 98 & 88 & 89 & 93 \\
France & & 79 & 82 & 76 & 84 & 114 & 115 \\
Italy & & 59 & 59 & 49 & 68 & 96 & 111 \\
Spain & & & & & 32 & 56 & 81 \\
Japan & & 24 & 32 & 42 & 20 & 95 & 143 \\
\hline
\end{tabular}

SOURCES: Broadberry (1996; 1997a); van Ark (1994).

cribed in detail in Broadberry (1993; 1994a). The basic methodology is to obtain benchmark estimates of labour productivity levels from production census material and extrapolate to other years using time series of real output and employment. In this respect, the methodology is very similar to that of Maddison (1995), and used for a recent study of productivity in manufacturing since 1950 by van Ark (1993). However, in manufacturing, it is possible to provide independent checks on the accuracy of the time series extrapolations because of the existence of a number of historical studies of comparative labour productivity levels. For the pre-World War II period the benchmark checks are based on the methodology of Rostas (1948) using physical indicators, while for the post-1945 period benchmark estimates are based on comparisons of value added converted to a common currency using relative factory gate prices, following the approach of Paige and Bombach (1959).

It should be noted that most historical studies of comparative productivity in manufacturing have compared Britain bilaterally with other countries. Hence Table 2 is reported with the UK as the numeraire country rather than the US, since bilateral comparisons are not strictly transitive. To facilitate comparisons between productivity levels in manufacturing and the whole economy Table 3 also provides figures for productivity in the whole economy with the UK as numeraire. In fact Table 3 is not quite the 


\section{TABLE 3}

Comparative labour productivity for the whole economy

(UK GDP per employee $=100)$

\begin{tabular}{lrrrrrrr}
\hline & 1870 & 1913 & 1929 & 1938 & 1950 & 1973 & 1992 \\
\hline UK & 100 & 100 & 100 & 100 & 100 & 100 & 100 \\
USA & 86 & 116 & 139 & 131 & 154 & 151 & 132 \\
Canada & 61 & 95 & 99 & 86 & 125 & 127 & 119 \\
Australia & 126 & 121 & 109 & 111 & 111 & 107 & 102 \\
Germany & 60 & 78 & 79 & 82 & 66 & 112 & 116 \\
Netherlands & 89 & 91 & 113 & 103 & 93 & 124 & 111 \\
Norway & 41 & 49 & 62 & 67 & 74 & 90 & 99 \\
Sweden & 46 & 58 & 59 & 69 & 90 & 105 & 96 \\
Denmark & 57 & 76 & 91 & 88 & 94 & 103 & 98 \\
France & 52 & 64 & 75 & 73 & 72 & 117 & 129 \\
Italy & 38 & 46 & 51 & 54 & 56 & 93 & 103 \\
Spain & & 52 & & & 37 & 89 & 98 \\
Japan & 18 & 23 & 33 & 38 & 29 & 85 & 103 \\
\hline
\end{tabular}

SOURCE: Derived from Maddison (1995).

same as a rebased Table 2, because Table 3 uses the number of employees as the labour input rather than the number of hours worked, since there is little reliable information on hours worked by sector before World War II. The figures of van Ark (1993) for manufacturing in the post-1950 period suggest that hours remain substantially longer in Japan than in all other countries, which makes Japanese productivity performance less impressive on a per hour basis, while there has been a sizeable fall in annual hours worked in Continental Europe during the 1980s, bringing productivity on a per hour basis closer to US levels.

Now comparing Tables 2 and 3 there are some striking differences in levels and trends. First, as noted in Broadberry (1993), in manufacturing there has been no clear trend over the last 120 years or so in comparative labour productivity performance between the three major exporting nations of $\mathrm{Bri}$ tain, Germany and the US. Over this long period, labour productivity in US manufacturing has fluctuated around a level of about twice the British level, while German manufacturing labour productivity has fluctuated around a level broadly equal to the British level. This contrasts strikingly with the position at the whole economy level, where the US has pulled substantially ahead of Britain from a position of broad equality in 1870 , and Germany has come from a productivity level about $60 \%$ of the British level to a sizeable 
productivity advantage over Britain. Clearly, then, the US forging ahead between 1870 and 1950 at the whole economy level cannot be explained simply in terms of productivity growth in manufacturing, although given the scale of the productivity gap in this sector, there is some role for the expansion of the share of the labour force in US manufacturing. Similarly, Germany's catching up of Britain at the whole economy level cannot be explained by trends in manufacturing productivity, but must be attributed to trends in other sectors and sectoral reallocation of labour, particularly the reduction of the labour force in low productivity agriculture.

Second, whereas the whole economy data in Table 3 are generally interpreted as consistent with global convergence (i.e. all countries converging on the same level of labour productivity or living standards), it is rather easier to identify a number of separate convergence clubs in the manufacturing data of Table 2 and hence to see a process of local convergence. The countries have been ordered in Table 2 to identify these separate convergence clubs by informal means, since there are insufficient observations to use the formal methods proposed by Durlauf and Johnson(1992). It is useful, I believe, to identify different convergence paths in the New World, Northern Europe, Southern Europe and Asia.

For the New World, the figures in Table 2 suggest a high level of labour productivity in manufacturing relative to Britain in the United States throughout the period since 1870 . For the other New World countries, although there are periods of high labour productivity relative to the UK, the trends are rather different. Although there does appear to be local convergence in North American manufacturing for much of the twentieth century, this follows a dramatic period of catching-up by Canada in the first decade of the twentieth century (Altman, 1987). However, to really capture the local convergence process in North America it is necessary to consider performance across US states. Barro and Sala-i-Martin (1991) find unconditional convergence across US states, albeit in overall economic activity rather than in manufacturing alone. Despite initially high levels of labour productivity, Australian manufacturing has suffered a serious decline in its relative productivity position. This relative decline in Australian manufacturing has been worse than the relative decline at the whole economy level. Long run trends in the manufacturing sector of the New World, then, caution against simple claims of global convergence.

Within Europe there is evidence of local convergence along two paths in the North and the South. In Germany, the Netherlands, Norway, Sweden and Denmark, labour productivity in manufacturing has fluctuated around 
the British level throughout the twentieth century. Hence the expansion of the industrial sector, and particularly the reduction in the size of low productivity agriculture, have been important factors in explaining the catching-up on Britain which occurred at the whole economy level, particularly in Scandinavia and Germany. The picture is somewhat different in Southern Europe, however, with manufacturing labour productivity levels substantially lower than in Britain in the pre-World War II period. The figures for the post-1945 period, however, suggest that in France, Italy and Spain, convergence to average European productivity levels has been achieved both in manufacturing and at the whole economy level.

Turning to Asia, there has been a dramatic catching-up spurt by Japan, particularly in the post-1945 period. In contrast to the North European situation, where catching-up at the whole economy level has occurred without any substantial catching-up in manufacturing, in Japan the improvement in manufacturing has been much greater than at the whole economy level. Although Japan has now substantially overtaken European manufacturers on an output per worker basis and is continuing to catch-up with the US, it should be noted that on a per hour worked basis German and Japanese labour productivity levels in manufacturing are now broadly similar, as Japanese hours are substantially longer.

On the basis of these trends, convergence at the whole economy level should not be seen primarily as a result of technology transfer within manufacturing. It seems clear that there are still substantial international differences in labour productivity levels in manufacturing, particularly between North America and Europe, and there is a large literature linking these productivity differences to choice of technology. It is not possible to survey fully this literature here and the interested reader is referred to Broadberry (1994a; 1995; 1997a). Nevertheless, it will be useful to summarise the key ideas.

Underlying the global convergence perspective is the notion that in a fully integrated world, productivity would be the same in all countries since they would all be using the same techniques. By contrast, the perspective offered here suggests that countries with different endowments and demand conditions will produce with different techniques and hence with different levels of labour productivity, an idea that draws on the famous Habakkuk (1962) thesis and in particular on the modified versions of Ames and Rosenberg (1968) and David (1975).

I would see the higher labour productivity in North America as a result of a greater reliance on mass production techniques in the US and flexible 
production techniques in Europe. The higher labour productivity in the US results from the greater capital intensity and resource intensity of production as well as from economies of scale associated with the production of standardised products. The greater prevalence of mass production in the US can be explained by both demand and supply factors. On the demand side, standardisation in the US was facilitated by the existence of a large, homogeneous home market in the US compared with fragmented national markets stratified by class differences in Europe, coupled with greater reliance on differentiated export markets (Rostas, 1948; Frankel, 1957; Chandler, 1990). On the supply side, resource intensive American machinery could not be adopted on the same scale in Europe, where resource costs were considerably higher (Ames and Rosenberg, 1968; Melman, 1956; Franko, 1976). Factor endowments reinforced these technological choices, with abundant skilled labour in Europe making continued reliance on flexible production profitable (Harley, 1974).

I would see the two technologies as coexisting so long as progress in one technology can be matched by imitation or adaptation in the other technology. Although for most of the period under consideration in this paper technological leadership rested with American mass production technology, forcing European firms to adapt to survive, in the first half of the nineteenth century technological leadership rested with British craft production technology (Broadberry, 1994a; 1994b). Furthermore, since the late 1960s there has been a revival in flexible production methods, with technological leadership shifting to Germany and Japan, and American firms being forced to adapt to survive. Note, however, that these changes in technological leadership have not been accompanied by changes in labour productivity leadership; throughout the period since 1820, at least, factor proportions and demand conditions have given the US a labour productivity advantage. Note also that simply copying technology from abroad without adaptation would be unlikely to be a successful strategy because business opportunities that are available to everyone cannot be profitable for everyone. This is recognised widely in the business strategy literature, and has been argued forcefully in a historical context by Hannah (1995). Indeed, it has been argued that one reason for Britain's poor performance in manufacturing compared with Germany during the post-1945 period was that Britain copied the United States too closely, while Germany built on its strategic asset of a skilled labour force (Broadberry and Wagner, 1996).

This coexistence of competing technologies, with both seen as rational in their respective environments, can be modelled along lines suggested by 
David (1975). Initial differences in factor proportions will be transmitted through time so long as technological progress can be characterised by local learning. Although «macro inventions» may appear to offer a country the opportunity to break free from such a technological «lock-in», in practice decisions on when or how to apply the new technology will be influenced by current factor proportions and demand conditions. This can be seen as an endogenous growth model in a stochastic environment with learning effects, and is consistent with the absence of global convergence. As well as showing up in the productivity figures, the differences in technology between countries can be seen in the detailed evidence of writers making factory visits in different countries, going back at least to the 1850s (Rosenberg, 1969; Anglo-American Council on Productivity, 1952; Daly et al., 1985).

This brief survey of the evidence from manufacturing suggests that even amongst the advanced industrial economies the long run evidence is best viewed as supporting local rather than global convergence. In particular, there has been a persistent, substantial labour productivity gap between Europe and North America.

\subsection{Comparative Labour Productivity Outside Manufacturing}

Estimates of comparative labour productivity levels in non-manufacturing sectors for Britain, the United States and Germany are provided in Broadberry (1997b; 1997c). As with manufacturing, the methodology has been to obtain benchmark estimates of comparative labour productivity levels for the mid-twentieth century and use time series of output and employment for extrapolation to other years. Again, additional benchmark estimates can be used to provide independent checks on the accuracy of the time series extrapolations.

Figures on comparative levels of labour productivity by sector for the United States and the United Kingdom are given in Table 4, taken from Broadberry (1997b) ${ }^{2}$. For the pre-1920 period, employment data are only

2 The comparative productivity level for the aggregate economy in Table 4 differs in detail from the pattern in Table 3 because I have been constrained to use aggregate GDP series that are available on a disaggregated basis. Thus, whereas Maddison (1995) uses the Department of Commerce series for the United States during the period 1929-50, I have used Kendrick (1961). However, the largest difference arises from Maddison's (1995) decision to use a variable weight index for the United States during the period since 1950 in preference to the official fixed weight index. Benchmark estimates for 1910,1937 and 1950 support the broad outlines of Table 4 (Broadberry, 1997b). 


\section{TABLE 4}

Comparative levels of labour productivity by sector: The United States and the United Kingdom (UK = 100)

\begin{tabular}{lrrrrr}
\hline & $1869 / 71$ & $1879 / 81$ & $1889 / 91$ & $1899 / 01$ & $1909 / 11$ \\
\hline Agriculture & 86,9 & 98,1 & 102,1 & 106,3 & 103,2 \\
Mineral Extraction & 103,1 & 99,3 & 109,0 & 147,3 & 162,0 \\
Manufacturing & 182,5 & 170,7 & 193,8 & 196,5 & 202,7 \\
Construction & 95,5 & 138,8 & 164,3 & 139,7 & 198,5 \\
Utilities & 55,8 & 74,5 & 113,5 & 128,1 & 149,5 \\
Transport/commun. & 110,0 & 146,9 & 167,1 & 226,8 & 217,4 \\
Distribution & 66,9 & 107,9 & 97,0 & 107,1 & 120,0 \\
Finance/Services & 64,1 & 58,4 & 53,2 & 71,6 & 77,9 \\
Government & 114,3 & 108,6 & 102,6 & 111,2 & 95,8 \\
GDP & 89,8 & 95,8 & 94,1 & 108,0 & 117,7 \\
\hline
\end{tabular}

\begin{tabular}{lccccc}
\hline & $1919 / 20$ & 1929 & 1937 & 1950 & 1960 \\
\hline Agriculture & 128,0 & 109,7 & 103,3 & 126,0 & 153,1 \\
Mineral Extraction & 228,2 & 248,9 & 232,1 & 376,5 & 618,4 \\
Manufacturing & 205,6 & 250,0 & 208,3 & 262,7 & 243,0 \\
Construction & 234,2 & 133,7 & 107,8 & 177,6 & 235,5 \\
Utilities & 295,5 & 335,9 & 359,3 & 573,4 & 719,9 \\
Transport/Commun. & 250,6 & 231,5 & 283,4 & 348,4 & 318,8 \\
Distribution & 109,0 & 121,9 & 119,8 & 135,2 & 143,2 \\
Finance/Services & 103,6 & 101,5 & 96,1 & 111,5 & 112,3 \\
Government & 97,9 & 99,4 & 100,0 & 116,2 & 110,2 \\
GDP & 133,3 & 139,4 & 132,6 & 166,9 & $\mathbf{1 6 7 , 9}$ \\
\hline
\end{tabular}

\begin{tabular}{lccrr}
\hline & 1968 & 1973 & 1979 & 1990 \\
\hline Agriculture & 156,7 & 131,2 & 156,1 & 151,1 \\
Mineral Extraction & 700,9 & 668,0 & 156,6 & 119,1 \\
Manufacturing & 242,8 & 215,0 & 202,6 & 175,2 \\
Construction & 204,5 & 146,6 & 129,7 & 98,5 \\
Utilities & 767,9 & 590,8 & 523,9 & 389,8 \\
Transport/Commun. & 336,8 & 303,3 & 302,7 & 270,5 \\
Distribution & 147,9 & 149,6 & 153,8 & 166,0 \\
Finance/Services & 121,3 & 118,0 & 118,3 & 101,0 \\
Government & 104,4 & 101,7 & 96,5 & 93,2 \\
GDP & 164,2 & 152,3 & 145,5 & 133,0 \\
\hline
\end{tabular}

NOTES: Extrapolations based on 1937 benchmarks.

SOURCE: Broadberry (1997b). 
available at intervals of a decade. Hence, for example, the 1869/71 figure compares output per employee in the US in 1869 with output per employee in the UK for 1871.

Perhaps the most striking finding is that over the last 120 years or so, Anglo-American labour productivity gaps have remained smaller in agriculture and services than in industry. The good productivity performance of British agriculture in the nineteenth century has been noted by Crafts (1985), who argues that Britain's main achievement during the industrial revolution was to create an unusually large industrial sector, which was actually quite labour intensive and therefore not characterised by particularly high labour productivity. It should be borne in mind that the high labour productivity of British agriculture reflected both the composition of output and the degree of capital intensity. The composition effect arose as the product mix shifted away from grain towards pastoral products in response to cheap grain imports from the New World. By 1908, the Agricultural Census noted that livestock accounted for almost $71 \%$ of net output in British agriculture. Thus while the United States supplied the world with cheap grain, the shrinking band of British farmers concentrated on livestock and livestock products, although even here they faced stiff competition from the New World and parts of Continental Europe. As Rostas (1948: 80) noted, the highest levels of agricultural labour productivity were recorded in the parts of the New World concentrating on pastoral products, especially Australia and New Zealand, and including Argentina before World War II. The high capital intensity in British agriculture reflected the moves towards «high farming» in response to the increased competition from abroad (Jones, 1968).

The relatively good performance of British services has been noted by a number of authors in recent years, including Lee (1986), Gemmell and Wardley (1990) and Rubinstein (1993), and it is reassuring to see that this is reflected in the comparative labour productivity figures. However, one caveat that should be borne in mind here is the difficulty of measuring output in non-marketed service sectors. In the national accounts, the trend of real output in these sectors is usually proxied by employment, effectively imposing zero labour productivity growth. In an international comparison the equivalent assumption that comparative real output is proxied by comparative employment builds in a comparative labour productivity ratio of 100 . Given the growing share of non-marketed services in GDP, especially since World War II, it may be expected that 
there will be a bias towards convergence in the national accounts data (Griliches, 1994) ${ }^{3}$.

A second general finding is that there has been a high degree of stability in the Anglo-American labour productivity difference in a number of sectors. The persistence of the productivity difference in manufacturing has already been noted. In addition, there is a high degree of persistence of the productivity ratios in agriculture, distribution, finance/services and government ${ }^{4}$. Mineral extraction and utilities are easily the most volatile sectors, with transport and communications and construction also exhibiting above average volatility ${ }^{5}$. This reminds us of the two basic ways in which the aggregate productivity ratio can change; first, through changes in the productivity ratios within individual industries, but secondly, also through structural change between sectors when productivity ratios vary across sectors.

A third point concerns the special nature of the volatility in construction. Whereas in the other volatile sectors there is a clear upward trend in the US/UK labour productivity ratio, this is not so obviously the case with construction. Rather, in this sector the fluctuations are more akin to inverse Kuznets cycles or long swings, with British labour productivity approaching American levels in British building booms. Although this pattern of inverse cycles has been much discussed in the literature on the Atlantic economy in the nineteenth century, its continuation into the twentieth century has been much less noted (Lewis, 1965; Thomas, 1973).

The results of a similar exercise for the Germany/UK comparison are reported in Table 5, taken from Broadberry (1997c). The sectoral breakdown is similar, except that finance has been included with distribution rather than professional and public services because of German data constraints for the pre-1959 period. Also, output in the government sector has been explicitly proxied by employment here ${ }^{6}$. As in the US/UK case,

In Table 4, the small fluctuations in comparative labour productivity that occur in the government sector should be seen as residual error, arising from slightly different assumptions built into the relationship between the growth of real output and employment in the two countries

+ However, the latter arises from the way that output in the government sector is proxied largely by employment trends.

s The degree of volatility can be measured by the coefficient of variation. The stable sectors have coefficients of variation of less than 0.2 , mineral extraction and utilities have cv's of about 0.6 , while construction and transport/communications have cv's of about 0.3 .

${ }^{6}$ Hoffmann's (1965) government output series for Germany includes education and culture. 


\section{TABLE 5}

Comparative levels of labour productivity by sector: Germany and the United Kingdom $(U K=100)$

\begin{tabular}{lrrrrr}
\hline & 1871 & 1881 & 1891 & 1901 & 1911 \\
\hline Agriculture & 55,7 & 54,7 & 53,7 & 67,2 & 67,3 \\
Mineral Extraction & 55,9 & 72,1 & 80,9 & 86,4 & 101,2 \\
Manufacturing & 92,6 & 88,7 & 94,0 & 98,8 & 119,3 \\
Construction & 76,1 & 113,7 & 90,1 & 100,3 & 117,7 \\
Utilities & 31,3 & 49,9 & 64,2 & 93,0 & 103,8 \\
Transport/Commun. & 96,8 & 126,7 & 147,5 & 195,1 & 216,9 \\
Dist'n/Finance & & 38,6 & 45,9 & 49,7 & 52,5 \\
Prof./Pers. Services & 89,7 & 83,4 & 77,0 & 76,6 & 76,3 \\
Government & 97,8 & 95,5 & 94,6 & 104,1 & 98,2 \\
GDP & 59,5 & 57,3 & 60,5 & 68,4 & 75,5 \\
\hline
\end{tabular}

\begin{tabular}{lrrrrr}
\hline & 1925 & 1929 & 1935 & 1950 & 1960 \\
\hline Agriculture & 53,8 & 56,9 & 57,2 & 41,2 & 47,8 \\
Mineral Extraction & 106,8 & 116,4 & 123,6 & 92,4 & 132,1 \\
Manufacturing & 95,2 & 104,7 & 102,0 & 96,0 & 114,8 \\
Construction & 65,7 & 50,2 & 70,6 & 84,2 & 102,0 \\
Utilities & 146,2 & 158,6 & 144,0 & 120,6 & 151,2 \\
Transport/Commun. & 140,0 & 151,2 & 132,4 & 122,0 & 117,0 \\
Dist'n/Finance & 47,1 & 50,3 & 54,3 & 50,7 & 64,2 \\
Prof./Pers. Services & 86,7 & 99,8 & 105,6 & 94,2 & 85,7 \\
Government & 100,1 & 100,0 & 100,0 & 96,9 & 111,8 \\
GDP & 69,0 & 74,1 & 75,7 & 74,4 & 94,5 \\
\hline
\end{tabular}

\begin{tabular}{lrrrrr}
\hline & 1968 & 1973 & 1979 & 1985 & 1990 \\
\hline Agriculture & 48,6 & 50,8 & 65,5 & 62,1 & 75,4 \\
Mineral Extraction & 135,3 & 138,1 & 45,1 & 25,0 & 17,5 \\
Manufacturing & 120,0 & 118,6 & 140,3 & 121,7 & 108,3 \\
Construction & 105,5 & 117,7 & 130,2 & 111,8 & 117,9 \\
Utilities & 146,7 & 139,2 & 164,5 & 142,7 & 130,0 \\
Transport/Commun. & 130,0 & 119,5 & 135,0 & 132,7 & 125,7 \\
Dist'n/Finance & 75,4 & 88,0 & 106,4 & 109,2 & 111,2 \\
Prof./Pers. Services & 101,3 & 98,4 & 103,1 & 105,3 & 120,5 \\
Government & 111,0 & 113,3 & 109,9 & 111,2 & 108,6 \\
GDP & 107,1 & 114,0 & 126,5 & 120,9 & 125,4 \\
\hline
\end{tabular}

NOTES: Extrapolations based on 1935 benchmarks.

SOURCE: Broadberry (1997c). 
differences introduced by minor changes to individual sectoral time series show up in the differences between the «total of above» and the «GDP» series, with the former calculated from the individual series actually used and the latter taking the uncorrected aggregate data from the original sources.

Taking the sample period as a whole, there has been a high degree of stability in the Anglo-German comparative productivity differences in a number of sectors. The persistence of broadly equal levels of labour productivity in manufacturing over this 120 year period has already been noted. The persistence of a substantial British labour productivity lead in agriculture is equally clear, although the persistence of broadly equal labour productivity in professional and personal services may be due at least partly to the use of employment as a proxy for output in substantial parts of this sector, something which is made explicit here in the treatment of government.

The largest German comparative productivity gains occurred in the distribution and finance sector throughout the period, in the utilities until 1979 , in mineral extraction until 1973, and in transport and communications before World War I. As in the US/UK case, construction followed a pattern of long swings, with British productivity higher when a British building boom coincided with a German building slump and with German productivity higher when a British building slump coincided with a German building boom.

\section{The Composition of Output}

The data in Tables 4 and 5 suggest that despite the trend towards convergence overall, substantial productivity gaps have persisted in individual sectors. It may be expected that in a country where some activities are subject to inevitable productivity disadvantages due to geographical factors, specialisation according to comparative advantage would dictate the contraction of those sectors and the expansion of other sectors in which that country is not geographically disadvantaged. To the extent that sectors are subject to diminishing returns, this would tend to equalise productivity between countries in each sector. However, it should be noted that not all output is tradeable, so there are limits to this process. Nevertheless, in tradeable sectors it is clear that this process has occurred to some extent; thus, for example, the rapid decline in the size of the British agricultural sector during the nineteenth century as cheap grain was imported from 
North America meant that the agriculture that survived in Britain remained high productivity, in contrast to the low productivity agriculture which continued to shelter behind tariffs in much of Continental Europe. However, the advantages of allowing the free operation of market forces to eliminate an industry or sector must be balanced against the need to accumulate physical and human capital in a path dependent world. It may be a mistake to sacrifice an industry in the face of a short run shock to relative prices if rebuilding capabilities in that industry is likely to prove difficult (Krugman, 1987).

We now chart explicitly the differences in structure between the three countries of Britain, Germany and the United States, and examine how these differences have changed over time. Figures on sectoral shares of employment in the three countries are given in Table 6. A number of features stand out. First, the small proportion of labour in agriculture in Britain before World War I meant that Britain's employment structure was unusually mature at this time, heavily skewed towards manufacturing and services. This lack of a low productivity agricultural sector is very important in explaining Britain's overall productivity leadership during the nineteenth century, which we have seen was not due to productivity leadership in Britain's manufacturing industry. This view is consistent with much of the recent revisionist work on the nature of the industrial revolution in Britain (Crafts, 1985).

Second, note that in 1950 Germany had a higher share of employment in agriculture than Britain had in 1871. The big release of labour from low productivity agriculture in Germany after World War II was an important factor in German catching up on Britain at the whole economy level. Note, however, that the release of labour from agriculture has been accompanied by an increase in employment in service industries rather than in manufacturing. Nevertheless, it should be noted that Germany stands out from the UK and the US in the post-World War II period by maintaining its share of employment in manufacturing and avoiding deindustrialisation.

Third, the rise in importance of service industries is notable in all three countries, particularly during the post-1950 period. The share of agriculture and production industries (mineral extraction, manufacturing, construction and utilities) has fallen from $74.8 \%$ to $24.3 \%$ in the US, from $64.6 \%$ to $30.5 \%$ in the UK and from $78.6 \%$ to $43.1 \%$ in Germany. This suggests that the problems of output measurement in the service sector have now become of paramount importance for contemporary measurement of international productivity differences. 
TABLE 6

Sectoral sbares of employment (\%)

A. United States

\begin{tabular}{lrrrrr}
\hline & 1870 & 1910 & 1930 & 1950 & 1990 \\
\hline Agriculture & 50,0 & 32,0 & 20,9 & 11,0 & 2,5 \\
Mineral Extraction & 1,5 & 2,8 & 2,2 & 1,5 & 0,6 \\
Manufacturing & 17,3 & 22,2 & 21,3 & 25,0 & 15,3 \\
Construction & 5,8 & 6,3 & 5,9 & 5,5 & 5,2 \\
Utilities & 0,2 & 0,5 & 0,8 & 0,9 & 0,7 \\
Transport/Commun. & 4,6 & 8,1 & 8,6 & 6,0 & 4,0 \\
Distribution & 6,1 & 9,1 & 11,7 & 18,7 & 22,0 \\
Finance/Services & 12,2 & 17,1 & 21,4 & 21,3 & 40,2 \\
Government & 2,3 & 1,9 & 7,2 & 10,1 & 9,5 \\
Total & 100,0 & 100,0 & 100,0 & 100,0 & 100,0 \\
\hline
\end{tabular}

B. United Kingdom

\begin{tabular}{lrrrrr}
\hline & 1871 & 1911 & 1930 & 1950 & 1990 \\
\hline Agriculture & 22,2 & 11,8 & 7,6 & 5,1 & 2,0 \\
Mineral Extraction & 4,0 & 6,3 & 5,4 & 3,7 & 0,6 \\
Manufacturing & 33,5 & 32,1 & 31,7 & 34,9 & 20,1 \\
Construction & 4,7 & 5,1 & 5,4 & 6,3 & 6,7 \\
Utilities & 0,2 & 0,6 & 1,2 & 1,6 & 1,1 \\
Transport/Commun. & 5,4 & 7,7 & 8,3 & 7,9 & 5,5 \\
Distribution & 7,5 & 12,1 & 14,3 & 12,2 & 19,5 \\
Finance/Services & 19,5 & 20,2 & 20,9 & 19,5 & 37,5 \\
Government & 3,0 & 4,1 & 5,2 & 8,8 & 7,0 \\
Total & 100,0 & 100,0 & 100,0 & 100,0 & 100,0 \\
\hline
\end{tabular}

C. Germany

\begin{tabular}{lrrrrr} 
C. Germany & 1875 & 1913 & 1935 & 1950 & 1990 \\
\hline Agriculture & 49,5 & 34,5 & 29,9 & 24,3 & 3,4 \\
Mineral Extraction & 1,5 & 2,8 & 1,7 & 2,8 & 0,6 \\
Manufacturing & 24,7 & 29,5 & 30,0 & 31,4 & 31,4 \\
Construction & 2,8 & 5,3 & 5,9 & 7,2 & 6,7 \\
Utilities & 0,1 & 0,3 & 0,6 & 0,7 & 1,0 \\
Transport/Commun. & 1,9 & 3,8 & 4,8 & 5,6 & 5,6 \\
Dist'n/Finance & 6,0 & 11,2 & 13,5 & 13,2 & 16,3 \\
Prof./Pers. Services & 10,0 & 8,3 & 8,8 & 7,9 & 19,9 \\
Government & 3,5 & 4,3 & 4,8 & 6,9 & 15,1 \\
Total & 100,0 & 100,0 & 100,0 & 100,0 & 100,0 \\
\hline
\end{tabular}

SOURCE: Broadberry (1997b; 1997c). 


\subsection{Analysis by Period}

It is instructive to consider the evolution of Anglo-American and AngloGerman productivity differences during three periods. During the period 1870-1910, the national income figures suggest that at the aggregate level, the United States forged ahead of Britain. However, there was only a very slight increase in the American labour productivity lead in manufacturing at this time. The large aggregate US gain resulted mainly from faster labour productivity growth in several non-manufacturing sectors, including mineral extraction, utilities and transport and communications, together with the effects of structural change. Of particular importance was the decline in the share of the labour force in agriculture and the growing importance of manufacturing, since both value added per worker within the US and the US productivity lead over Britain were much greater in manufacturing than in agriculture. It seems unlikely that Britain could have avoided falling behind during this period on account of her inferior resource endowments.

One striking feature of the Anglo-German comparison in Table 4 is that by 1911 Germany had a labour productivity lead over Britain in all industrial sectors, but still managed to attain an aggregate labour productivity level only three-quarters of the British level. This suggests that Germany paid a high price in terms of overall living standards for the policy of agricultural protection, which kept out cheap New World grain but prevented the release of labour to higher value added activities.

Turning to the period 1910-50, the United States continued to forge ahead at the aggregate level, although gains across the two world wars were offset by a faltering during the Depression of the 1930 s, which hit the United States much harder than Britain, allowing Britain temporarily to narrow the gap. Manufacturing also followed this pattern during 1910-50, although larger US trend gains occurred in mineral extraction, utilities and transport and communications ${ }^{7}$. However, although British relative decline was more broadly based during this period covering the two world wars than before World War I, again it would be premature to talk of «failure», because it is not clear that better alternatives were available as the world economic system disintegrated. To the extent that the British economy before World War I was driven by its position at the centre of a global system, the growth

7 The strong US productivity gains in mineral extraction and utilities are largely the result of composition effects, particularly the growing importance of oil, natural gas and hydroelectricity in the United States. 
of autarky between the wars was a major threat to British living standards. The response was a shift of focus towards the Empire (Broadberry, 1997b). Imperial Preference gave Britain access to food and raw materials on advantageous terms, while helping to maintain access to markets for British manufacturers. Although this was clearly helpful in maintaining British incomes and living standards in the short run, in the long run there were also adverse consequences, since patterns of trade and capital flows were seriously distorted, creating problems of adjustment later as the world economy re-integrated (Broadberry, 1997b).

Britain continued to retain a sizeable labour productivity lead over Germany during the period 1910-50. As in the pre-World War I period, Britain's lead over Germany was in agriculture and services rather than in industry, together with the effects of a much larger agricultural sector in Germany. The American forging ahead during this period was relative to Europe as a whole, and it was only after World War II that Britain was caught up by most West European countries (Maddison, 1991: 53).

The third period, 1950-90, is characterised by a slow process of catching-up by Britain on the United States. However, the most striking feature of the catching-up process in Britain was its slowness compared with Germany and much of the rest of Western Europe, where catching-up on the United States proceeded much more rapidly. To some extent, slower catching-up in Britain was only to be expected, given that the aggregate labour productivity gap with the United States was smaller than in other West European countries (Feinstein, 1990). Nevertheless, as we have seen this was not always the case at a more disaggregated level. Slow British catching-up in industrial sectors can be explained to some extent by the historical legacy of heavy dependence on Commonwealth markets and the resultant hesitancy in seizing the opportunities arising from the reintegration of the world economy. However, most commentators also note problems arising from the adoption of American mass production technology and the resulting poor industrial relations. It is noticeable that British manufacturing productivity performance has improved dramatically during the $1980 \mathrm{~s}$ with the rejuvenation of flexible production technology, more suited to British conditions (Piore and Sabel, 1984; Milgrom and Roberts, 1990; Broadberry, 1997a) ${ }^{8}$.

8 The British improvement in mineral extraction from 1973 is largely the result of a composition effect, with the rise of the North Sea oil sector. The discovery of North sea gas also had an impact on the utilities sector. 
The spectacularly successful German recovery from World War II has been acclaimed widely as an «economic miracle» (Dumke, 1990; Giersch et al., 1992; Hennings, 1982). By the late 1960s, Germany had overtaken Britain in terms of aggregate labour productivity, having begun the 1950s with overall labour productivity less than three quarters of the British level. In Table 5 we see that by 1968, Germany had lower labour productivity than Britain only in agriculture and distribution/finance. In Table 6 we see that during the post-World War II period there has been a dramatic shift of labour from agriculture to services in Germany. In Britain, by contrast, agriculture was already very small by 1950 , so that the growth of employment in services has been at the expense of manufacturing.

\section{DISAGGREGATION BY INCOME}

\subsection{International Comparisons of Real Wages}

Williamson (1995) has constructed an alternative data set which offers a perspective on long run convergence. He presents annual estimates of real wage levels for fifteen countries, going back to 1830 in some cases. The data are presented in Table 7 at benchmark years for ease of comparison with earlier tables.

The first stage in the construction of the data is to obtain time series for the nominal wages of urban, unskilled labourers, usually based on the hourly, daily or weekly wages of building labourers. The nominal wage series are then deflated by cost of living indices, usually for urban areas with weights based on budget studies of unskilled labourers. The resulting real wage series are then used to extrapolate from benchmark estimates of comparative real wage levels obtained by comparing nominal wages in each country with nominal wages in Britain and converting to a common currency using a purchasing power parity (PPP). Williamson establishes three benchmarks at 1905, 1927 and 1975, which means that the time series have discontinuities at 1913 and 1945.

Williamson's results paint a plausible picture, which points towards local rather than global convergence. Williamson identifies three groups; the English speaking New World (USA, Canada and Australia); Latin New and Old World (Argentina, Italy and Spain); Other Old World. These groups correspond to the New World, South European and North Euro- 
TABLE 7

Comparative levels of reals wages $(U K=100)$

\begin{tabular}{lrrrrrrr}
\hline & 1870 & 1913 & 1929 & 1938 & 1950 & 1973 & 1988 \\
\hline UK & 100 & 100 & 100 & 100 & 100 & 100 & 100 \\
USA & 167 & 154 & 174 & 229 & 214 & 167 & 117 \\
Canada & 143 & 199 & 122 & 118 & 104 & 164 & 129 \\
Australia & 184 & 116 & 134 & 128 & 84 & 76 & 54 \\
Argentina & 88 & 84 & 105 & 90 & 59 & 35 & 22 \\
Germany & 84 & 84 & 94 & 79 & 69 & 107 & 105 \\
Netherlands & 75 & 65 & 130 & 120 & 96 & 110 & 93 \\
Norway & 41 & 75 & 115 & 117 & 118 & 116 & 112 \\
Sweden & 41 & 89 & 112 & 113 & 118 & 152 & 123 \\
Denmark & 52 & 92 & 149 & 144 & 114 & 143 & 128 \\
Ireland & 71 & 82 & 106 & 98 & 75 & 92 & 109 \\
France & 72 & 60 & 71 & 67 & 49 & 78 & 79 \\
Belgium & 87 & 85 & 48 & 47 & 90 & 109 & 97 \\
Italy & 38 & 50 & 41 & 42 & 84 & 95 & 100 \\
Spain & 74 & 46 & 51 & 47 & 57 & 67 & 92 \\
\hline
\end{tabular}

SOURCE: Williamson (1995, Table A2.1).

pean groups identified in the earlier section on manufacturing, apart from the linking together of the Latin New and Old Worlds via the inclusion of Argentina in the sample.

Williamson (1995: 157) argues that Abramovitz (1986) and Baumol (1986) pay insufficient attention to the strength of the forces for convergence before World War I, concentrating instead on the period of convergence after World War II. To some extent this is explained by the data; in Maddison's (1995) GDP per hour data set, the fall in the coefficient of variation is clearly much greater in the period after 1950 than before World War I, as can be seen in Table 1 . This is not the case in the real wage data set if the years 1850 to 1900 are chosen for the pre-World War I period, as Williamson (1995: 159) notes. Since the pre-World War I and post-World War II periods are seen as periods of global factor and product market integration, in contrast to the interwar period, Williamson (1995: 162) argues that we should look to market integration rather than technology transfer as the key to convergence. Williamson (1996) provides a survey of much of the empirical work in this area, stressing the globalisation of commodity markets through international trade and labour markets through migration in the pre-World War I period. Such a conclusion does fit broadly with the scep- 
ticism expressed earlier concerning the role of technology transfer in manufacturing as a source of convergence.

\subsection{Wages and the National Accounts}

GDP per worker can be broken down by income source, just as it was broken down by sector on the output side in Section III. This enables us to see how convergence of income per employee is related to factor price convergence. We begin with the national income identity:

$$
Y=w L+\pi K+\theta R
$$

where $Y$ is real GDP, $L$ employment, $K$ capital and $R$ resources, with factor prices $w, \pi$, and $\theta$ respectively for the real wage rate, the real profit rate and real resource rent respectively. Dividing through by employment yields:

$$
(Y / L)=w+\pi(K / L)+\theta(R / L)
$$

If we look at the US/UK comparison, we see from Table 3 that in terms of GDP per employee, the US came from behind to overtake the UK, rising from 86 to 116 between 1870 and 1913. Over the same period, Table 8 shows that in terms of real wages, there was a fall in the US lead from 167 to 154. The exclusion of Ireland from the British real wage data does not explain the discrepancy, because Ireland was gaining real wage ground against the US more quickly than Britain was. Furthermore, something similar happened between most European countries and the US over this period; real wages converged, but GDP per employee diverged.

How can the real wage and GDP per employee data be reconciled for the period 1870-1913? The national income identity can help here, but let us distinguish between skilled and unskilled real wages and employment, with subscripts $u$ and $s$ :

$$
(Y / L)=w_{u}\left(L_{u} / L\right)+w_{s}\left(L_{s} / L\right)+\pi(K / L)+\theta(R / L)
$$

Since the forces for divergence dominated over this period, it suggests that convergence in unskilled real wages was offset by divergence in other factor prices or composition effects. I would see the driving force behind divergence at the aggregate level as the faster growth of resource intensity and 
TABLE 8

Total gross savings as a ratio of GDP at current market prices (\%)

\begin{tabular}{lcccccc}
\hline & $1870-1889$ & $1890-1913$ & $1914-1938$ & $1939-1949$ & $1950-1973$ & $1974-1987$ \\
\hline UK & 13,9 & 13,6 & 8,3 & 1,6 & 17,9 & 19,2 \\
USA & 19,1 & 18,3 & 17,0 & 15,2 & 19,7 & 18,0 \\
Canada & 9,1 & 12,2 & 14,4 & 19,3 & 22,5 & 21,5 \\
Australia & 11,2 & 13,0 & 12,4 & 13,8 & 24,4 & 22,0 \\
Germany & & & 12,9 & & 27,5 & 24,0 \\
Netherlands & & & 15,2 & & 26,8 & 22,9 \\
France & 12,8 & 14,7 & & & 23,5 & 22,3 \\
Japan & 12,4 & 12,3 & 16,7 & 23,3 & 32,8 & 32,9 \\
Korea & & & 4,3 & & 8,1 & 27,9 \\
Taiwan & & 9,6 & 25,5 & & 19,9 & 33,2 \\
India & & 5,8 & 7,4 & 6,7 & 12,8 & 20,2 \\
\hline
\end{tabular}

NOTES: Canada excludes inventories 1870-1926; Australia excludes inventories 1870-1913; Germany, entry in third column is for 1925-38; Netherlands, entry in third column is for 1921-38; Japan excludes inventories 1885-1940 and entry in first column is for 1885-89; Korea, entry in fifth column is for 1953-73; Taiwan excludes part of inventories 1903-1938, and entry in second column is for 1903-13.

SOURCE: Maddison (1992: 185).

capital intensity in the US. Although in a closed economy context this would be expected to lead to faster real wage growth in the US, it is possible in an open economy that migration offset this, at least among unskilled workers. It would therefore be interesting to know what happened to skilled wages.

In general, then, there is no necessity for individual factor prices and overall incomes to follow the same patterns of convergence or divergence. Movements in one factor price may be offset by movements in other factor prices, and there may be composition effects from changing factor proportions.

\section{DISAGGREGATION BY EXPENDITURE}

\subsection{Consumption and Savings}

Maddison (1992) examines the issue of the split between consumption and savings for a sample of eleven countries over the period since 1870. This 
matters because in a world of imperfect capital mobility, investment in an individual country will be constrained by domestic savings, and convergence of GDP per head therefore requires convergence of savings rates. Gross savings are measured as the sum of domestic investment and investment abroad. We begin with the national accounting identity:

$$
Y=C+I+G+N X
$$

where $Y$ is national income, $C$ private consumption, I domestic investment, $G$ government consumption and $N X$ net exports. Dividing through by national income, and writing lower case letters to denote variables as a proportion of national income:

$$
1=c+i+g+n x
$$

Rearranging, the gross savings rate (s) is given by:

$$
s=1-c-g=i+n x
$$

Since the balance of payments must sum to zero, net exports must equal net investment abroad (plus the current account item net transfers abroad). Hence Maddison measures gross savings as the sum of gross fixed domestic investment (non-residential plus dwellings), net investment in inventories and net investment abroad. Note that the use of the term net here refers to the balance of positive and negative flows; since there are serious difficulties with adjustments for depreciation, Maddison chooses to work with gross rather than net savings.

Total gross savings as a share of GDP at current market prices for eleven countries are shown in Table 8 . The data are broadly consistent with the convergence hypothesis. There tends to be an inverse relationship between the level of per capita income and the gross savings rate; there is an acceleration in the savings and investment rates while poorer countries are catching up, and this is followed by a decline once most of the income gap has been eliminated. In Korea, Taiwan and India, the decline in the savings rate has not yet set in because these countries are still catching up. The position is less clear in Japan, because although on a per hour basis labour productivity is still a long way behind the US, the gap is much smaller on the basis of GDP per head of the population. 


\section{TABLE 9}

Total government expenditures as a proportion of GDP at current prices (\%)

\begin{tabular}{lrrrrrc}
\hline & 1913 & 1929 & 1938 & 1950 & 1973 & 1987 \\
\hline UK & 13,3 & 23,8 & 28,8 & 34,2 & 41,5 & 45,2 \\
USA & 8,0 & 10,0 & 19,8 & 21,4 & 31,1 & 37,0 \\
Germany & 17,7 & 30,6 & 42,4 & 30,4 & 42,0 & 47,3 \\
Netherlands & 8,2 & 11,2 & 21,7 & 26,8 & 45,5 & 59,7 \\
France & 8,9 & 12,4 & 23,2 & 27,3 & 38,8 & 56,6 \\
Japan & 14,2 & 18,8 & 30,3 & 19,8 & 22,9 & 33,9 \\
Average & 11,7 & 17,8 & 27,7 & 26,7 & 37,0 & 46,6 \\
CV & 0,31 & 0,42 & 0,27 & 0,19 & 0,21 & 0,20 \\
\hline
\end{tabular}

NOTES: Netherlands, entry in first column for 1910; France and UK, entries in final column for 1986.

SOURCE: Maddison (1992), p. 196.

\subsection{The Role of Government}

Maddison (1992) also provides data on the share of government in economic activity for six countries over the period since 1913 . Table 9 sets out figures on total government expenditure, including transfers, as a proportion of GDP at current market prices. Although there is a relative price effect, so that the increase would look less dramatic in constant prices, it is clear that there has been a real expansion in the role of government, with the rise of the welfare state, macroeconomic management, microeconomic regulation and direct state production (Pratten, 1990: 163). We have included here the coefficient of variation, which shows that as the share of government spending has risen, dispersion has fallen. There is thus evidence of convergence in this item of expenditure, at least among the six countries considered by Maddison. However, differences between countries remain quite large. The difference between the Netherlands and the US, for example, is quite striking, with divergence occurring only since World War II. Convergence at the aggregate level, then, does not seem to require convergence of the government spending share.

\subsection{Preferences}

The above results suggest that whilst persistent differences in preferences between private and public consumption are consistent with con- 
vergence at the aggregate level, persistent differences in preferences between current and future consumption are not. This is because in a world of imperfect capital markets, savings affect investment, which in turn affects growth. The choice between public and private consumption, however, does not affect investment and growth in any straightforward way.

\section{CONCLUDING COMMENTS}

This paper has examined the convergence process at a disaggregated level in a historical context. A three-way disaggregation of the national accounts by output, income and expenditure has revealed a wealth of diversity, both over time and across countries, i.e. history and geography matter. Countries can specialise according to comparative advantage, and convergence at the aggregate level can occur through changes in structure as well as through convergence at the micro level. Similarly, changes in factor proportions may lead to convergence of aggregate incomes without requiring convergence of all factor prices at the micro level. Also, differences in preferences may persist, so that individual components of expenditure do not need to converge in line with aggregate expenditure. Convergence at the aggregate level, then, does not necessarily lead to uniformity. Vive la différence!

\section{REFERENCES}

ABRAmovitz, M. (1979): «Rapid Growth Potential and its Realisation: The Experience of the Capitalist Economies in the Postwar Period», in Malinvaud, E. (ed.), Economic Growth and Resources, Proceedings of the Fifth World Congress of the International Economic Association, Vol.I, London: Macmillan.

(1986): «Catching-Up, Forging Ahead and Falling Behind», Journal of Economic History, 46, pp. 385-406.

Altman, M. (1987): «A Revision of Canadian Economic Growth: 1870-1910 (A Challenge to the Gradualist Interpretation)», Canadian Journal of Economics, 20, pp. 86-113.

AMES, E. and ROSENBERG, N. (1968): «The Enfield Arsenal in Theory and History», Economic Journal, 78, pp. 827-942.

Anglo-American Council on Productivity (1952): Final Report, London: AACP.

ARK, van B. (1993): «International Comparisons of Output and Productivity: Manufacturing Productivity Performance of Ten Countries from 1950 to 1990», (Groningen Growth and Development Centre Monograph Series, n. ${ }^{\circ} 1$ ). (1994): «Comparative Output and Productivity in Spanish Manufacturing, 1950-1989», (unpublished, University of Groningen). 
Barro, R. J. and SAla-I-Martin, X. (1991): «Convergence Across States and Regions», Brookings Papers on Economic Activity, pp. 107-182.

BAUMOL, W. J. (1986): «Productivity Growth, Convergence and Welfare: What the Long Run Data Show», American Economic Review, 76, pp. 1072-1159.

BROADBERRY, S. N. (1993): «Manufacturing and the Convergence Hypothesis: What the Long Run Data Show», Journal of Economic History, 53, pp. 772-795.

- (1994a): «Technological Leadership and Productivity Leadership in Manufacturing since the Industrial Revolution: Implications for the Convergence Debate», Economic Journal, 104, pp. 291-302.

-(1994b): «Comparative Productivity in British and American Manufacturing During the Nineteenth Century», Explorations in Economic History, 31, pp. 521-548.

- (1995): «Comparative Productivity Levels in Manufacturing since the Industrial Revolution: Lessons from Britain, America, Germany and Japan», Structural Change and Economic Dynamics, 6, pp. 71-95.

- (1996): «Convergence: What the Historical Record Shows», in van Ark, B. and Crafts, N.F.R. (eds.), Quantitative Aspects of Postwar European Economic Growth, Cambridge: Cambridge University Press, pp. 327-346.

- (1997a): The Productivity Race: British Manufacturing in International Perspective, 1850-1990, Cambridge: Cambridge University Press.

- (1997b): «Forging Ahead, Falling Behind and Catching-Up: A Sectoral Analysis of Anglo-American Productivity Differences, 1870-1990», Research in Economic History, 17, pp. 1-37.

- (1997c): «Anglo-German Productivity Differences 1870-1990: A Sectoral Analysis», European Review of Economic History, 1, pp. 247-267.

BroAdBerRY, S. N. and WAGNER, K. (1996): «Human Capital and Productivity in Manufacturing During the Twentieth Century: Britain, Germany and the United States», in van ARK, B. and CRAFTS, N. F. R. (eds.), Quantitative Aspects of Postwar European Economic Growth, Cambridge: Cambridge University Press, pp. 244-270.

ChANDLER, Jr., A. D. (1990): Scale and Scope: The Dynamics of Industrial Capitalism, Cambridge, MA.: Harvard University Press.

ClARK, C. (1940): The Conditions of Economic Progress, London: Macmillan.

CORNWALl, J. (1977): Modern Capitalism: Its Growth and Transformation, London: Martin Robertson.

CRAFTS, N. F. R. (1985): British Economic Growth During the Industrial Revolution, Oxford: Oxford University Press.

Daly, A., Hitchens, D. M. and WAGNER, K. (1985): «Productivity, Machinery and Skills in a Sample of British and German Manufacturing Plants», National Institute Economic Review, 111, pp. 48-61.

David, P. A. (1975): Technical Choice, Innovation and Economic Growth, Cambridge: Cambridge University Press.

DE LONG, J. B. (1988): «Productivity Growth, Convergence and Welfare: Comment», American Economic Review, 78, pp. 1138-1154.

DUMKE, R. (1990): «Reassessing the Wirtschaftswunder: Reconstruction and Postwar Growth in West Germany in an International Context», Oxford Bulletin of Economics and Statistics, 52, pp. 451-491. 
Durlauf, S. N. and Johnson, P. A. (1992): «Local versus Global Convergence Across National Economies», (Working Paper n. ${ }^{\circ} 3996$, National Bureau of Economic Research, Cambridge, MA).

FEINSTEIN, C. H. (1988): «Economic Growth since 1870: Britain's Performance in International Perspective», Oxford Review of Economic Policy, 4(1), pp. 1-13.

FEINSTEIN, C. H. (1990): «Benefits of Backwardness and Costs of Continuity», in Graham, A. and Seldon, A. (eds.), Government and Economies in the Postwar World: Economic Policies and Comparative Performance, 1945-85, London: Routledge, pp. 284-293.

Frankel, M. (1957): British and American Manufacturing Productivity, Urbana: University of Illinois.

Franko, L. G. (1976): The European Multinationals: A Renewed Challenge to American and British Big Business, London: Harper \& Row.

Gemmell, N. and WardLeY, P. (1990): «The Contribution of Services to British Economic growth, 1856-1913», Explorations in Economic History, 27, pp. 299-321.

Giersch, H., Paqué, K. H., and Schmieding, H. (1992): The Fading Miracle: Four Decades of Market Economy in Germany, Cambridge: Cambridge University Press.

GomulKa, S. (1971): Inventive Activity, Diffusion and the Stages of Economic Growth, Aarhus: Institute of Economics.

Griliches, Z. (1994): «Productivity, R\&D and the Data Constraint», American Economic Review, 84, pp. 1-23.

HabAKKuK, H. J. (1962): American and British Technology in the Nineteenth Century, Cambridge: Cambridge University Press.

HANNAH, L. (1995): «The American Miracle, 1875-1950, and After: A View in the European Mirror», Business and Economic History, 24, pp. 197-220.

HARLEY, C. K. (1974): «Skilled Labour and Choice of Technique in Edwardian Industry», Explorations in Economic History, 2, pp. 391-414.

Hennings, K. H. (1982): «West Germany», in Boltho, A. (ed.), The European Economy: Growth and Crisis, Oxford: Oxford University Press, pp. 472-501.

Hoffmann, W. G. (1965): Das Wachstum der deutschen Wirtschaft seit der Mitte des 19. Jahrhunderts, Berlin: Springer.

JONES, E. L. (1968): The Development of English Agriculture, 1815-1873, London: Macmillan.

KendrICK, J. W. (1961): Productivity Trends in the United States, Princeton: National Bureau of Economic Research.

KrugmaN, P. (1987): «The Narrow Moving Band, the Dutch Disease, and the Competitive Consequences of Mrs. Thatcher», Journal of Development Economics, 27, pp. 41-55.

LEE, C. H. (1986): The British Economy Since 1700: A Macroeconomic Perspective, Cambridge: Cambridge University press.

LEWIS, J. P. (1965): Building Cycles and Britain's Growth, London: Macmillan.

MAdDISON, A. (1964): Economic Growth in the West, London: Allen \& Unwin.

- (1982): Phases of Capitalist Development, Oxford: Oxford University Press.

(1991): Dynamic Forces in Capitalist Development, Oxford: Oxford University Press. 
MADDISON, A. (1992): «A Long-Run Perspective on Saving», Scandinavian Journal of Economics, 94, 181-196.

- (1995): Monitoring the World Economy, 1820-1992, Paris: Organisation for Economic Cooperation and Development.

Melman, S. (1956): Dynamic Factors in Industrial Productivity, Oxford: Blackwell.

MILGROM, P. and ROBERTS, J. (1990): «The Economics of Modern Manufacturing: Technology, Strategy and Organisation», American Economic Review, 80, pp. 511-528.

Nelson, R. R. and WRIGHT, G. (1992): «The Rise and Fall of American Technological Leadership: The Postwar Era in Historical Perspective», Journal of Economic Literature, 30, pp. 1931-1964.

Paige, D. and Bombach, G. (1959): A Comparison of National Output and Productivity of the United Kingdom and the United States, Paris: Organisation for European Economic Cooperation.

PIORE, M. J. and SABEL, C. F. (1984): The Second Industrial Divide: Possibilities for Prosperity, New York: Basic.

PratTen, C. F. (1990): Applied Macroeconomics, (2nd edn.), Oxford: Oxford University Press.

ROSENBERG, N. (1969) (ed.), The American System of Manufactures, Edinburgh: Edinburgh University Press.

ROSTAS, L. (1948): Comparative Productivity in British and American Industry, Cambridge: National Institute of Economic and Social Research

RubinsteIn, W. D. (1993): Capitalism, Culture and Economic Decline in Britain, 1750-1990, London: Routledge.

Thomas, B. (1973): Migration and Economic Growth: A Study of Great Britain and the Atlantic Economy, (2nd edn.), Cambridge: Cambridge University Press.

Williamson, J. G. (1995): «The Evolution of Global Labor Markets since 1830: Background Evidence and Hypotheses», Explorations in Economic History, 32, pp. 141-196.

- (1996): «Globalization, Convergence, and History», Journal of Economic History, 56, pp. 277-306. 